\title{
THE MEETING OF THE AMERICAN MEDICAL ASSOCIATION.
}

$\mathrm{T}^{\mathrm{H}}$ HE sixty-third annual session of the American Medical Association, held in Atlantic City, N. J., June 4-7, 1912, is now a matter of history and cannot help but have a lasting influence on the progress of pharmacy in the United States. The meeting was attended by upwards of 3000 physicians from all sections of the country, who, divided in fourteen sections, listened to the reading of more than 400 papers.

As in former years, the Section on Pharmacology and Therapeutics presented a program that was of unusual interest to pharmacists and not a few members of the American Pharmaceutical Association from Philadelphia, New York and other cities attended the sessions of this section and took part in the discussion. Professor Joseph P. Remington at the opening session of the Section presented an address as Chairman of the delegation from the American Pharmaceutical Association and the members of the American Pharmaceutical Association present were, on motion, accorded the privileges of the floor.

Among matters of direct interest to pharmacy discussed in this Section, the first on the program was embodied in the symposium on patents and trade-marks. The discussion on this subject was participated in by retail druggists, physicians, manufacturers and others interested in the granting or non-granting of patents and trade-mark registration on commercial substances used as medicines. As a direct outcome of the discussion a Committee was appointed to request that the Board of Trustees of the American Medical Association sue for the annullment of the trade-mark registration of an article used as medicine. On motion the House of Delegates was requested to instruct the Council on Health and Public Instruction to secure legislation abolishing product patents on chemical substances used as medicines.

The desirability of a more restricted materia medica was discussed from the standpoint of the chemist by W. A. Puckner, Chicago, that of the pharmacist by Henry P. Hynson, Baltimore, medical instruction, by E. Lefevre, New York, the medical practitioner by Oliver T. Osborne, New Haven. Further discussion was participated in by a number of the members present, the general trend of the discussion being in harmony with the action of the Committee on Useful Remedies of the American Medical Association in presenting for discussion and use a list of important medicaments to which examination in materia medica subjects by state medical examining and licensing boards might be restricted, and which list might be used as the basis for instruction in materia medica subjects by teachers in medical schools.

In a joint meeting with the Section on Preventive Medicine and Public Health, the use of intestinal antiseptics and the standarization of disinfectants was discussed at length and it was shown that many of the commercially available disinfectants were inefficient and that standarization of this class of articles must be insisted on.

Dr. Robert A. Hatcher, New York, and Dr. Carey Eggleston, New York, presented comprehensive papers on the action of digitalis and digitalis-like bodies, and these communications will no doubt go far toward establishing more definite knowledge of these important drugs. 
A symposium on drug standards and drug standarization was participated in by Professor Joseph P. Remington, who presented a report of progress of the U.S. P. revision; L. F. Kebler, who discussed the quality of drugs on the market; R. H. True, who reviewed the experiments made in drug cultivation by the Bureau of Plant Industry of the United States Department of Agriculture; Horatio C. Wood, Jr., who discussed the ideals and limitations of bio-assay; Henry Kraemer, who reviewed the history and the possibilities of the retail pharmacist as a purveyor of pure drugs, and Julius $H$. Comroe, who discussed prescribing versus dispensing on the part of medical practitioners.

The concluding symposium, of the section program, on anesthesia was one of vital importance, not alone to physicians and pharmacists, but also to patients generally who must assume the risks attending a general or partial narcosis. In the course of this symposium Professor Charles Baskerville, of New York, presented a comprehensive review of the work that he and his students have done on the chemistry of inhalation anesthetics, and incidentally pointed out the differences now existing in the standards for the several anesthetics included in different pharmacopœias. He asserted that these standards varied widely and that many, including those of the U. S. P., permitted the presence of dangerous contaminations that should not be allowed. Statistics relating to mortality from anesthetics were discussed by several physicians and the use of spinal anesthesia or analgesia was commented on at length. Although the papers presented in this symposium will well be worth careful perusal on the part of pharmacists who are interested in supplying the best that the market affords in the way of anesthetics and of preventing contamination or adulteration of the articles supplied by them.

It is manifestly impractical to review at length the proceedings of the several sections. Pharmacists who are interested will find much of value in the several communications and in the discussions on them which will be printed in the Journal of the American Medical Association. One feature of the meeting that might be commented on in passing is the revised principles of medical ethics adopted by the House of Delegates. Section 1 is particularly interesting in that it defines the object of a profession as follows:

"Section 1. A profession has for its prime object the service it can render to humanity; reward or financial gain should be a subordinate consideration. The practice of medicine is a profession. In choosing this profession an individual assumes an obligation to conduct himself in accord with its ideals."

Section 4 of chapter 3 relates specifically to the practice of pharmacy and reads as follows:

"Sec. 4. By legitimate patronage, physicians should recognize and promote the profession of pharmacy; but any pharmacist, unless he be qualified as a physician, who assumes to prescribe for the sick, should be denied such countenance and support. Moreover, whenever a druggist or pharmacist dispenses deteriorated or adulterated drugs, or substitutes one remedy for another designated in a prescription, he thereby forfeits all claims to the favorable consideration of the public and physicians."

Another feature of the meeting that was of more or less direct interest to pharmacists was the exhibition, both scientific as well as commercial, held an- 
nually in connection with the meeting of the American Medical Association. This year the exhibits were unusually well arranged and readily accessible at all times - of the day. The commercial exhibition was notably free from objectionable proprietary medicines and in keeping with the scientific exhibition was generally recognized as being of educational value. The exhibitions made by the Public Health and Marine-Hospital Service and by the Chemical Laboratory of the American Medical Association attracted considerable attention and contained much material of direct interest to pharmacists.

The absence of any exhibit by pharmacists was noticed by a number of the members of the American Medical Association who expressed regret that members of the American Pharmaceutical Association did not see fit to follow up the exhibits made on previous occasions, and the suggestion was variously made that the American Pharmaceutical Association itself undertake to finance an annual exhibition of official preparations in connection with the meeting of the American Medical Association.

M. I. WILBERT.

\section{THE MILWAUKEE CONVENTION.}

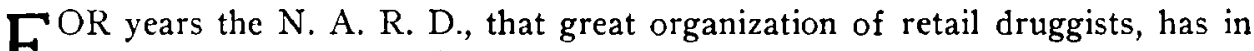
F many ways shown its friendly regard for our own association, and consequently, it is with pleasure that The Journal calls attention to the coming N. A. R. D. convention at Milwaukee, during the week of August 12. The date was originally set for August 26 , but a change was made necessary on account of its conflicting with the meeting of the American Bar Association, which is to be held in the same city.

Milwaukee is famous for various things, not the least of them being the large and beautiful auditorium in which the N.A. R. D. meeting and the National Drug Show will be held. Instead of the usual extemporized booths, made from pine boards covered with muslin, the auditorium provides artistic booths, uniform in style and size, and so constructed as to display the various exhibits to the best advantage and admitting of decorative effects of various kinds.

The past year has been a great one for the N. A. R. D., and has been marked by positive accomplishments both in presenting opposition to objectionable legislative measures and in the advocacy of wise and just ones. On numerous occasions, officers and committees of that organization have been in consultation with officers and committees of our own society upon questions of importance to the whole body of pharmacy, particularly with regard to the proper revision and correction of the Richardson Bill, which seeks to amend the Food and Drug Act. It is to be hoped that future years will bring about a still closer coöperation for common purposes between these, the two greatest organizations in pharmacy, and that they may become as closely united in active and effective work as they have been in sympathy. It is also to be hoped that at the coming meetings, both bodies will formulate and settle upon definite legislative propositions and other policies upon which they can vigorously coöperate during the coming year. When a measure has received the assent of both societies, there is little doubt but that it will represent wisely and broadly the interests of pharmacy, and when the force 